\title{
FOOD INSECURITY AS A BASIS FOR DRAFTING A STRATEGIC FOOD SOVEREIGNTY PLAN: A CASE STUDY OF THE KUTAI KARTANEGARA DISTRICT, INDONESIA
}

\author{
Subejo ${ }^{1,4}$, Al Fidiashtry ${ }^{2}$, Candra Aryudiawan ${ }^{3,4}$, Suadi $^{3,4}$, Awaluddin ${ }^{4}$ L, \\ MuH ARIS MARFAI ${ }^{2,4}$
${ }^{1}$ Department of Agricultural Socio-economics, Faculty of Agriculture, Universitas Gadjah Mada, Yogyakarta, Indonesia
${ }^{2}$ Department of Environmental Geography, Faculty of Geography, Universitas Gadjah Mada, Yogyakarta, Indonesia
${ }^{3}$ Department of Fisheries, Faculty of Agriculture, Universitas Gadjah Mada, Yogyakarta, Indonesia
${ }^{4}$ Centre for Economic and Public Policy Studies, Universitas Gadjah Mada, Yogyakarta, Indonesia

Manuscript received: July 3, 2017

Revised version: October 15, 2017

\begin{abstract}
Subejo, Fidiashtry A., Aryudiawan C., Suadi, Awaluddin L, Marfai M.A., 2017. Food insecurity as a basis for drafting a Strategic Food Sovereignty Plan: A case study of the Kutai Kartanegara District, Indonesia. Quaestiones Geographicae 36(4), Bogucki Wydawnictwo Naukowe, Poznań, pp. 141-158. 2 tables, 3 figs.

ABSTRACT: This study aims to analyse food sovereignty strategies in an effort to eradicate poverty in a micro-scale region by strengthening its food security status. The research was conducted in the Kutai Kartanegara District East Kalimantan Province in Indonesia. Food insecurity status in the study area was determined based on nine food security indicators. The 237 villages in the Kutai Kartanegara District were ranked based on four classifications of vulnerability to food insecurity. The results showed that $3.80 \%$ of the villages were highly vulnerable, $5.06 \%$ were vulnerable, $8.86 \%$ were slightly vulnerable and $82.28 \%$ were food secure. While Kutai Kartanegara was a food secure district, in order to maintain its food security status and enhance the performance of the villages that are still vulnerable to food insecurity, local government, and related stakeholders must work together to develop strategies to improve agricultural productivity, increase the region's human resources capability and strengthen its infrastructure so food can be more readily accessed.
\end{abstract}

KEY WORDS: food security, food sovereignty, agriculture, Kutai Kartanegara, Indonesia

Corresponding author: subejo@ugm.ac.id

\section{Introduction}

Food is broadly acknowledged as a basic human need. Together with water and energy needs, food security has become one of the most important issues for the sustainability of national and global public life. Studies have shown that more and more countries and relevant stakeholders, such as regional, national, and international institutions, governments, and citizens, are paying serious attention to the development of the agricultural sector and the availability and affordability of food, and access to it (Subejo 2011; Subejo et al. 2015). According to Pinstrup-Andersen (2009) and Suhardjo (1994), food security is the ability of stakeholders at the global, national, local, community or household level to provide enough food in a variety of ways. According to Steckley (2016) and Li and Zhang (2017), food security occurs when the community physically, socially, and economically has continuous access to food that is adequate, safe, and nutritious so that people can meet their food requirements and be healthy and active. In contrast, food insecurity is defined 
as the inability to obtain sufficient and suitable food for a healthy and active life (Mammen et al. 2009; Musemwa et al. 2015; Azeem et al. 2016; Potochnick 2016; Stephens et al. 2017).

Communities usually challenged by food insecurity are those in which people are poor, affected by natural disasters, or live in a place that is geographically far from food resources, thereby limiting their access to food (Kollannoor-Samuel et al. 2011; Crush and Caesar 2014; Barnidge et al. 2017; Denney et al. 2017). Food insecurity may be chronic or temporary (transient) (WFP 2009). Chronic food insecurity is a long-term condition in which people are unable to meet their minimum food requirements. This situation is usually associated with structural factors, such as local climate, a soil type, a local government system, land ownership, the relationship between ethnicity and the education level, and many other factors, such as the availability of work or the gender ratio that cannot be changed quickly (Nalty et al. 2013; Markwick et al. 2014; Shone et al. 2017). Transient food insecurity is a short-term or temporary inability to meet minimum food requirements. This situation is usually associated with dynamic factors that change quickly, such as infectious diseases, natural disasters, displacement, changes in the market function, the debt level, migration, etc. (Tawodzera 2011; Jablonski et al. 2016). Continuous transient food insecurity can lead to decreasing ability of households to thrive; it can even turn into chronic food insecurity.

At the national and global levels, food security tends to focus only on food availability. The guarantee of the right to food fulfilment for every person at any time should not only cover the amount of food, it should also ensure its accessibility and affirm its security as well as the adequacy of its nutrients in accordance with healthy nutrition standards (Kneafsey 2013; Anderson 2013). A country that has satisfied those conditions will achieve national food sovereignty; thus, it will ensure the prosperity of its people (Chaifetz and Jagger 2014).

Indonesia is widely known as an agricultural and maritime country, and its land and ocean areas are rich in natural resources. Thus, it has the capability to produce food within its own borders in order to achieve national food sovereignty. In any country, food sovereignty can only be realised by a rapid, fundamental, and substantial change implemented through various agricultural development policies. This rapid fundamental change includes a revolution in the agricultural production and distribution system as well as the character of the national food consumption to support the performance of the food sector (Larochez-Dupraz and Huchet-Bourdon 2016).

The successful performance of the food sector is strongly associated with the development of macro-economic performance and, in general, the development of a country's agricultural sector (Koren and Bagozzi 2016). Recently, several studies have shown that there is a contradiction between macro-economic growth performance and a weak national agricultural micro-condition. According to Jamhari (2011), some Indonesian macro-economic indicators that seem to be quite prospective are: an economic growth of $6 \%$, relatively low inflation, foreign reserves amounting to USD 120 billion, a gross domestic product (GDP) ranked 16th, the population in which 16\% of people are members of the middle class, and a national budget of up to IDR 1,800 trillion (in 2015 it even exceeded IDR 2,000 trillion).

A country's agricultural sector plays an important role in its economic development, not only in relation to the GDP but also in terms of creating employment, generating income, and strengthening the country's currency so it has a healthy foreign exchange rate. The agricultural sector plays a crucial role as a provider of food for the community; thus, it can play a strategic role in national food security, which is closely related to social security, economic and political stability, and national security and defences. The agricultural sector also supports economic growth by the transfer of surplus labour from the agricultural sector to the industry sector; producing raw materials to increase industry and the services sector; generating foreign exchange through exporting products; providing financial capital for the development of other sectors and environmental services, such as minimising the impact of natural disasters, safeguarding germplasm resources, and maintaining soil fertility. In general, the agricultural sector's contribution to national and regional development has an economic, ecological, environmental, and socio-cultural function (Bommarco et al. 2013; De Miguel et al. 2014; Hassen et al. 2016).

However, in Indonesia, the macro-economic conditions and the performance of the 
agricultural sector are not as strong as they could be, as shown by the high volume and value of imports of various agro products. The volume of imports of some food commodities per year has exceeded 1 million tons. The IDR value of imports of the following five major commodities is quite substantial: wheat (up to IDR 23 trillion), soybeans (IDR 12 trillion), rice (IDR 9.5 trillion), maize (IDR 5.2 trillion), and salt (IDR 1.1 trillion) (Subejo et al. 2015). However, at the micro-level, food security is still not good. Based on the results of Jamhari's (2011) analysis, only 53\% of the households in Indonesia have a high level of food security. Of those food secure households, $66 \%$ are in urban areas and $44 \%$ are in rural areas. Another $57 \%$ of the households in Indonesia are still challenged by high levels of food insecurity.

Indonesia's food security status is still in a position that is relatively low compared to other Association of Southeast Asian Nations (ASEAN) countries. Subejo et al. (2015) reported a food security index score of 46.8 for Indonesia, which positions it in the sixth place behind Singapore, Malaysia, Thailand, Vietnam, and the Philippines. Indonesia's food security status is only slightly better than the food security status of Myanmar and Cambodia. In addition to the level of food security, Indonesia's poor micro-economic health can also be seen in the level of poverty. Based on Central Bureau of Statistics data (BPS 2013), there has been a slight decrease in the number of poor people in Indonesia. The poor in Indonesia have been defined as people who live under the poverty line, which is calculated every year by Central Bureau of Statistics at the local and national levels. However, the total number of poor people in Indonesia was still problematic; while the population decreased from 10.51 million in September 2012 to 10.33 million in March 2013, the number of poor people in urban areas only decreased by 0.18 million. In rural areas it decreased by 0.35 million (declining from 18.09 million in September 2012 to 17.74 million in March 2013). The latest data released by BPS (2015) and BPS (2016) show that the number of poor people in rural areas is 17.37 million, which is $14.81 \%$ of the total population in Indonesia. In the case of the Kutai Kartanegara District of East Kalimantan Province, the poverty line in urban areas in 2016 was IDR 535,137 / capita/month (USD 41.2) and in rural areas was IDR 510,041 / capita/month (USD 39.2). Most of the poor people in rural areas are farmers who own tenant farms and farm workers who produce food, but who also need access to it. This condition illustrates the complexity of the rural and agricultural issue in Indonesia.

Based on actual national problems, including the dynamics in the national agricultural sector, momentum to make fundamental and substantial changes in national agricultural development has emerged in Indonesia. An important classical study related to the design of strategies for agricultural development was a pioneering work by Mosher (1966), entitled Getting Agriculture Moving. A relatively new contribution to the literature is Lima Pilar Kedaulatan Pangan Nusantara (Five Pillars of Indonesian Food Sovereignty) by Subejo et al. (2015). Both studies generally emphasise five significant components that determine the success of agricultural development and food sovereignty: (1) the potential and capacity of natural resources; (2) the potential and capacity of human resources; (3) infrastructure and technology; (4) policies and regulations; and (5) the pattern of food consumption.

The achievement of food sovereignty, which includes food resources that can be sourced from food crops, livestock, plantations, and fisheries, should not only be global and national concern, but it should also be taken seriously by local government officials. The ability to provide food that is based on the capacity of local resources in each region strategically ensures high access to food for every citizen. On a national scale, the Indonesian Regional Medium-term Development Plan (RPJMN) 2015-2019 has prioritised programs related to food and nutrition. In order to achieve the stated goals, the government, through the Food Security Council and World Food Programme (WFP), created the Food Security and Vulnerability Atlas (FSVA). FSVA identifies the districts that are the most vulnerable to food insecurity and malnutrition and determines the causes of that vulnerability. FSVA uses 13 available indicators at the district level to measure various aspects of food security and nutrition. FSVA divides the food insecurity indicators into two groups: chronic and transient. Transient indicators explain the climate and environmental factors that affect availability and access to food, thus causing food insecurity. Chronic indicators measure food availability, food access, and food 
utilisation. The nine indicators related to chronic food insecurity were then combined into one composite indicator to describe the overall food security condition of a district. This information is then used to establish a priority level for each district. While the composite indicator of food security depicts the current situation of chronic food insecurity, it does not include an analysis of transient food security that is due to dynamic factors, such as climate and the environment.

While inequality of resources, the condition of the infrastructure, natural disasters, and climate change pose significant threats to national food security, these factors can affect each region differently, so each region must address and overcome these issues in its own way (Hanjra and Qureshi 2009; Rattan 2013; Retnowati et al. 2014; Paloviita et al. 2016). Thus, the local government plays a critical role in addressing and overcoming these issues, so it has every right to initiate and implement appropriate regional development policies (Dinc et al., 2003). Kutai Kartanegara in East Kalimantan Province is one of the districts in Indonesia that, currently, is relatively food secure in comparison to other districts in Indonesia. The Food Security Council and the World Food Programme (2015) stated that the Kutai Kartanegara District is ranked last out of six food security priority needs based on its food insecurity vulnerability status. Through Kutai Kartanegara's contribution to agriculture, forestry, and fisheries, its regional GDP value increased every year from 2010 to 2015 (from 6.42\% in 2010 to $9.97 \%$ in 2015). Kutai Kartanegara was chosen as the subject of this research study because, while at the national level it is one of the districts with the largest domestic budget for development programs and it is one of the country's food secure districts, its food security status at the micro-level has not yet been determined. Could a district's food security status at the national level also guarantee food security for all people in each its sub-districts and villages? In order to answer that question, further research is needed.

Although previous studies of FSVA have provided an important analysis of the food security status in Indonesia, the coverage of that country's national level of food security status is limited to the district level. This paper attempts to complement previous studies by expanding the prior analyses to address the sub-district and village level by choosing one specific district as its subject. This research aims to identify the food insecurity status in the Kutai Kartanegara District comprehensively based on nine indicators that could apply only in that specific region. Based on the insecurity status of each sub-district and village, the priority area can be ranked to determine which area has the most urgent food security needs and should be handled first. Recommendations and strategies were made based on the results, which, hopefully, could be used to support the local government in drafting policies and programs to address the food issue and eradicate poverty and hunger at the micro-scale level, in order to strengthen its food sovereignty.

\section{Methods}

To address the study's aims, data was collected and analysed, and then the findings were reported. A flowchart of the research design is shown in Fig. 1.

Primary and secondary sources were used to collect and store the data. Data were collected from primary sources directly through observation, interviews, surveying, mapping, and focus group discussions (FGDs) with relevant stakeholders such as Department of Marine Affairs and Fisheries, Department of Agriculture, Animal Husbandry Department, Agency for Regional Development Planning, Agricultural Extension Agency, NGOs, also local farmers and fishermen. Data were collected from secondary sources by reviewing previous studies and reports produced by related agencies. This research was mainly based on the evaluation and analysis of secondary data from the literature, which was obtained from the written reports of related institutional agencies and legislation as well as quantitative and qualitative data, such as region strategic planning reports, the region's regional long-term development plan (RPJPD), the region's regional medium-term development plan (RPJMD), the spatial zonation plan (RTRW), statistical data derived from a district in figures, a sub-district in figures, and the region's statistical report. In addition to secondary data, primary data were obtained from direct observations of agricultural and food sector development in the field, as well 


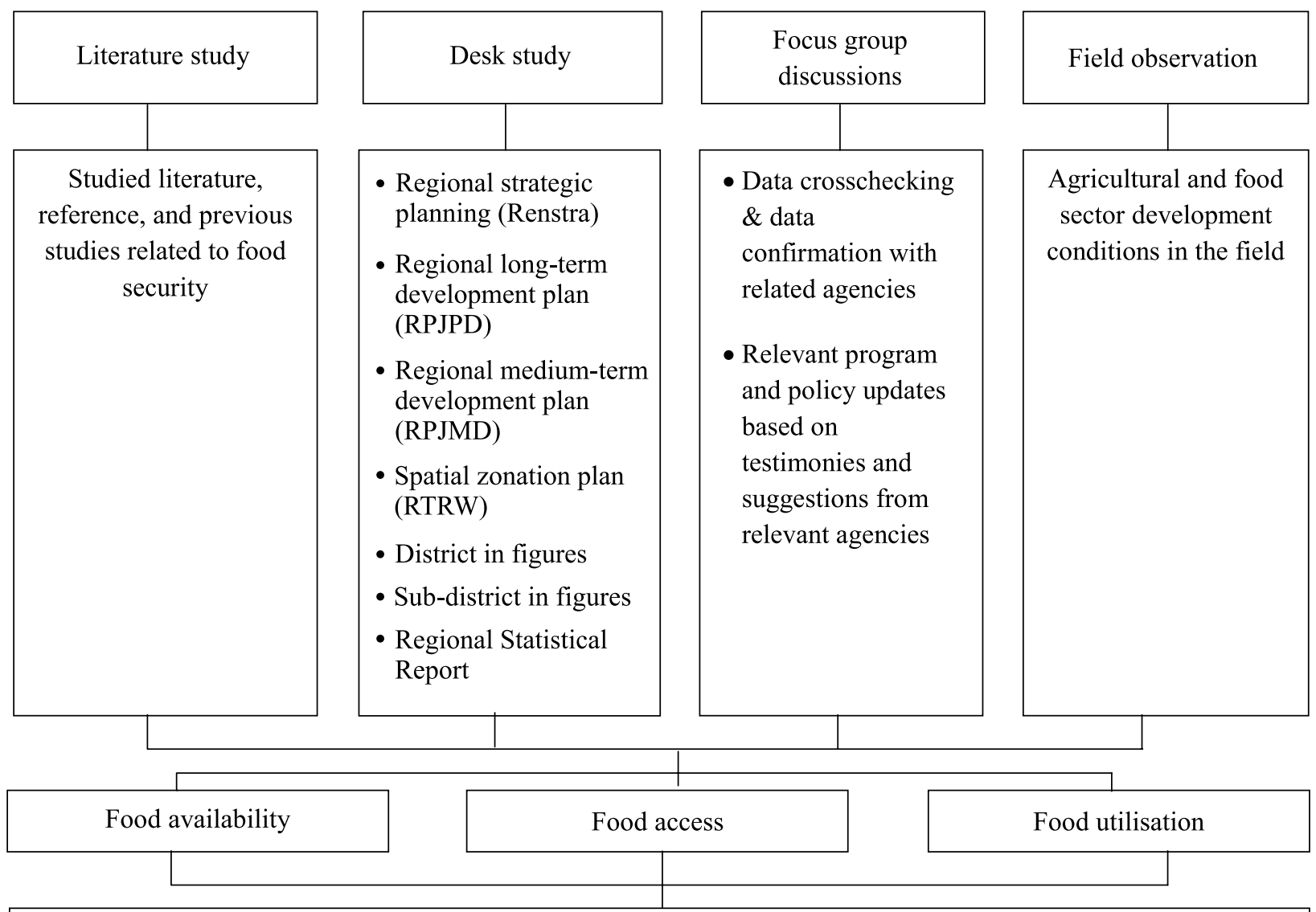

(1) ratio of the number of stalls to the households; (2) ratio of the number of stores to households; (3) ratio of the population to the minimum welfare value; (4) ratio of the number of households without access to electricity; (5) ratio of the number of villages with inadequate transportation connections; (6) ratio of the number of children not attending school; (7) ratio of the number of households without access to clean and safe drinking water; (8) ratio of the number of medical staff to the population; and (9) ratio of the number of households without access to a disposal facility

Classification of food insecurity status for each villages in Kutai Kartanegara District

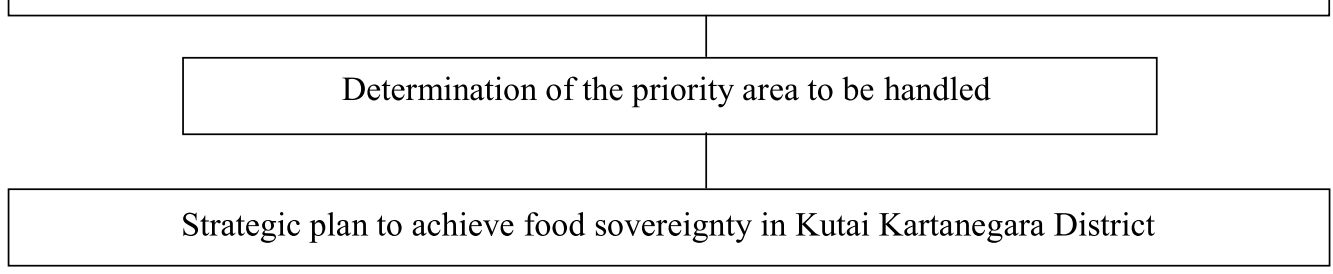

Fig. 1. Flowchart of the research design.

as the results obtained from the FGDs conducted by the researchers with district government officers and related stakeholders. The pool of data from all the collected ones was later categorised into separate data that were associated with food sector development in the district. The usable data were processed, classified, and analysed in order to address the research aims.

Food and nutrition security is a multi-dimensional issue that requires a range of parameters.
The food insecurity status of each village in the Kutai Kartanegara District was determined by using nine indicators related to three main dimensions of food security (food availability, food access, and food utilisation). The nine indicators that represent those dimensions are shown in Table 1. These nine indicators, each of which have different weight, were then combined into one composite indicator to produce the overall food security condition of the district, and then 
Table 1. Indicators used to defined food insecurity area in Kutai Kartanegara District.

\begin{tabular}{|l|l|c|}
\hline \multicolumn{1}{|c|}{ Indicators } & \multicolumn{1}{|c|}{ Definition of indicators } & Weight \\
\hline Ratio of the number of stalls to households & $\begin{array}{l}\text { Total number of stall in the village divided by total num- } \\
\text { ber of households }\end{array}$ & 0.06 \\
\hline Ratio of the number of stores to households & $\begin{array}{l}\text { Total number of stores in the village divided by total num- } \\
\text { ber of households }\end{array}$ & 0.38 \\
\hline $\begin{array}{l}\text { Ratio of the population to the minimum } \\
\text { welfare value }\end{array}$ & $\begin{array}{l}\text { Total number of population under minimum welfare value } \\
\text { divided by total number of population }\end{array}$ & -0.38 \\
\hline $\begin{array}{l}\text { Ratio of the number of households without } \\
\text { access to electricity }\end{array}$ & $\begin{array}{l}\text { Total number of households without electricity access } \\
\text { divided by total number of households }\end{array}$ & 0.45 \\
\hline $\begin{array}{l}\text { Ratio of the number of villages with ina- } \\
\text { dequate transport connection }\end{array}$ & $\begin{array}{l}\text { Total number of villages with inadequate transport co- } \\
\text { nnection divided by total number of villages }\end{array}$ & 0.42 \\
\hline $\begin{array}{l}\text { Ratio of the number of children not attending } \\
\text { school }\end{array}$ & $\begin{array}{l}\text { Total number children not attending school divided by } \\
\text { total number of children who should attending school } \\
\text { (7 years old for elementary school) }\end{array}$ & 0.04 \\
\hline $\begin{array}{l}\text { Ratio of the number of households without } \\
\text { access to clean and safe drinking water }\end{array}$ & $\begin{array}{l}\text { Total number of households without access to clean and } \\
\text { safe drinking water divided by total number of households }\end{array}$ & 0.11 \\
\hline $\begin{array}{l}\text { Ratio of number of medical staff to the popu- } \\
\text { lation }\end{array}$ & $\begin{array}{l}\text { Total number of medical staff divided by total number of } \\
\text { population }\end{array}$ & 0.54 \\
\hline $\begin{array}{l}\text { Ratio of the number of households without } \\
\text { access to a disposal facility }\end{array}$ & $\begin{array}{l}\text { Total number of households without access to a disposal } \\
\text { facility divided by total number of households }\end{array}$ & -0.04 \\
\hline
\end{tabular}

(Source: Kutai Kartanegara District Office, 2016).

the priority level of each village was ranked. Four priorities divided based on vulnerability status in each village at the Kutai Kartanegara District. Priority 1 is the category of villages which are highly vulnerable to food insecurity. Priority 2 is for villages which are vulnerable to food insecurity while priority 3 is for villages which are slightly vulnerable to food insecurity. Lastly, villages in priority 4 are the ones which are secure against food insecurity.

\section{Results and discussion}

\section{Study area}

The Kutai Kartanegara District is located in East Kalimantan Province; the district's capital is located in the Tenggarong sub-district. Kutai Kartanegara is the second largest district in East Kalimantan after East Kutai. Kutai Kartanegara occupies $24.38 \%$ of the total area of East Kalimantan; thus, the district covers an area of $27,263.10 \mathrm{~km}^{2}$. Administratively, it has 18 sub-districts and 237 villages, which are located at an altitude ranging between 0-2,000 $\mathrm{m}$ above sea level. Kutai Kartanegara is dominated by a steep slope, ranging from $15 \%$ to $40 \%$, which is a major constraint especially in the district's upstream region. In this kind of topography, land utilisation, such as infrastructure development, a ground transportation system, and even agricultural cultivation (especially for growing food) is very difficult. As the sea level of the land increases, the types of commodities that can be cultivated and manufactured become increasingly limited (Funakawa et al. 2009). Nevertheless, almost $40 \%$ of Kutai Kartanegara's terrain is flat, which is suitable for wetland cultivation.

The Kutai Kartanegara District is strongly influenced by its rainforest climate, with modest rainfall throughout the year (Agus et al. 2004); precipitation ranges between 2,000-4,000 mm/year. The average temperature of Kutai Kartanegara is $26^{\circ} \mathrm{C}$. Considering the physical characteristics of the region, Kutai Kartanegara has the potential of having many natural resources that can be used for local economic interests (Bosma et al. 2012). The region's potential economy, such as its agriculture, plantations, forestry, fisheries, and marine areas, which cover a total of 2,132,175 ha, would provide sufficient food for the district's 717,789 people (total population of the district in 2015) if it is managed wisely. However, the population significantly increased during the period of 2010-2015; in contrast, in 2010, only 627,378 people resided there. The average rate of population growth during the period is $2.37 \%$ per year. The highest population growth $(3.32 \%)$ occurred in 2011.The lowest population growth $(2.48 \%)$ 
was in 2015. It should have been anticipated that the high rate of population growth in the Kutai Kartanegara District would be followed by an increase in the need for food, healthcare facilities, education, and other systems that support the quality of life.

\section{Food insecurity status in the Kutai Kartanegara District}

At the national and regional level, upstream processes usually garner more attention for agricultural development, specifically in terms of increasing the capacity of agricultural production. In upstream processes, the development of access to land resources and the fulfilment of manufacturing needs and techniques are important. However, focusing too intently on these factors will not enable authorities to overcome the food sovereignty issue. Thus, the downstream aspect is also very important and must be developed. Many programmes have been implemented and much effort has been made to find solutions that address the agricultural context and national food policies. However, it appears that the outcome and impact of the success of agricultural development have not yet been significant. Moreover, it has failed to create sustainable food sovereignty at the level of households and communities. As mentioned above, the Kutai Kartanegara District consists of 18 sub-districts with a total of 237 villages. Fig. 2 shows the list of sub-districts and villages in the Kutai Kartanegara District.

Based on its food insecurity vulnerability status, determined by the nine indicators previously described, every village has been categorised into four groups based on its priority of need, ranging from the most food insecure village to the most food secure village. Priority 1 is the category of villages that are highly vulnerable to food insecurity. Priority 2 is the category of villages that are vulnerable to food insecurity. Priority 3 is the category of villages that are slightly vulnerable to food insecurity. Priority 4 is the category of villages that have adequate food security. Table 2 shows the number of villages in each priority area and their vulnerability status based on the analysis of the range/ratio of the nine food security status indicators to the number of households in the Kutai Kartanegara District.
Data from Table 2 were then processed and analysed by calculating and converting all the ratio values shown above into a composite indicator, and then classifying them to determine the priority area as well as the food insecurity level. Based on the final result of the classification using composite indicators, which was analysed and evaluated using data obtained from the Kutai Kartanegara District Office (2016), out of 237 villages in the Kutai Kartanegara District, nine were classified as being a Priority 1 area. Those villages are Muara Aloh, Jantur, Muara Muntai Ulu, Muara Muntai Ilir, Kayu Batu, Jantur Selatan, Tanjung Batuq Harapan, and Pulau Harapan (the Muara Muntai sub-district) and Pela Village (the Kota Bangun sub-district). The Priority 2 group consists of 12 villages from eight sub-districts: Batuq and Rebaq Rinding (the Muara Muntai sub-district), Enggelam (the Muara Wis sub-district), Muhuran and Sebelimbingan (the Kota Bangun sub-district), Mangkurawang (the Tenggarong sub-district), Suka Maju (the Tenggarong Seberang sub-district), Sidomulyo (the Anggana sub-district), Tunjungan and Liang Buaya (the Muara Kaman sub-district), and Lamin Telihan Village (the Kenohan sub-district). The Priority 3 group contains 21 villages, spread over 13 sub-districts: Muara Sembilang (the Samboja sub-district), Muara Kembang (the Muara Jawa sub-district); Sanga-sanga Muara (the Sanga-sanga sub-district); Jonggon Desa (the Loa Kulu sub-district); Jantur Baru (the Muara Muntai sub-district); Muara Enggelam (the Muara Wis sub-district); Sebulu Ilir and Sanggulan (the Sebuluv sub-district); Sepatin and Muara Pantauan (the Anggana sub-district); Makarti (the Marang Kayu sub-district); Teratak, Muara Kaman Ilir, Muara Siran, Kupang Baru, and Cipari Makmur (the Muara Kaman sub-district); Semayang, Kahala, Teluk Bingkai, and Lamin Pulut (the Kenohan sub-district); and lastly Perdana Village (the Kembang Janggutv sub-district). The Priority 4 group contains 195 villages, spread throughout 18 sub-districts; these villages are considered to have a food secure status.

At the sub-district level, the classification of food insecurity status is defined as: (1) high, if the number of villages classified as Priority 1 , Priority 2, and Priority 3 exceeds 30\%; (2) moderate, if the number of villages classified as Priority 


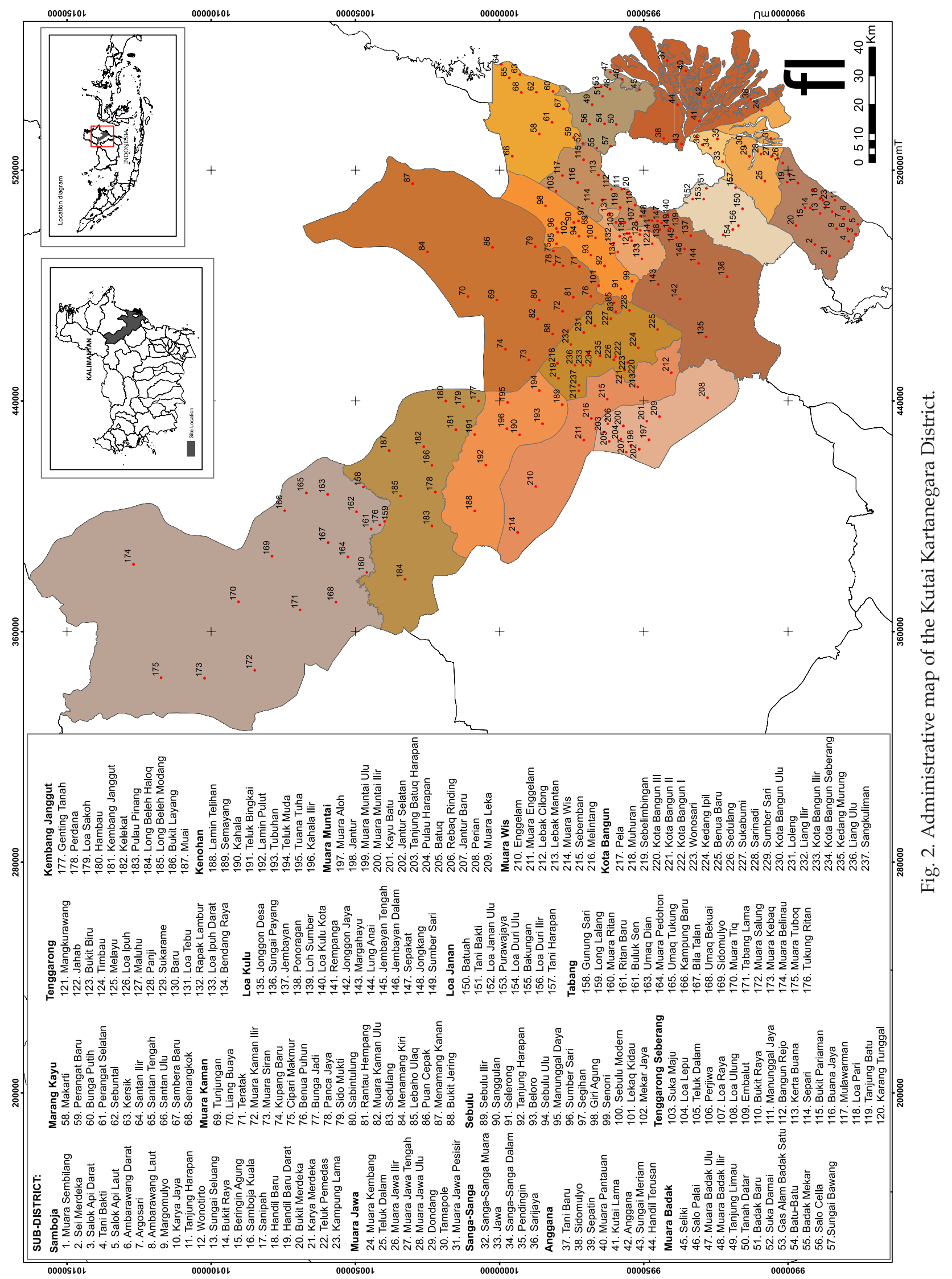


Table 2. FSVA indicators of the range/ratio of the nine food security status indicators to the number of households in Kutai Kartanegara District.

\begin{tabular}{|c|c|c|c|c|}
\hline Village priority & $\begin{array}{l}\text { Range of the number of stalls to the } \\
\text { number of households }\end{array}$ & Number of villages & Percentage $(\%)$ & Vulnerability status \\
\hline Priority 1 & 0.1417 & 59 & 25 & Highly vulnerable \\
\hline Priority 2 & 0.1371 & 60 & 25 & Vulnerable \\
\hline Priority 3 & 0.1304 & 59 & 25 & Slightly vulnerable \\
\hline Priority 4 & 0.0000 & 59 & 25 & Secure \\
\hline \multicolumn{2}{|r|}{ Total number } & 237 & 100 & \\
\hline Village priority & $\begin{array}{l}\text { Range of the number of stores to the } \\
\text { number of households }\end{array}$ & Number of villages & Percentage (\%) & Vulnerability status \\
\hline Priority 1 & 0.1392 & 59 & 25 & Highly vulnerable \\
\hline Priority 2 & 0.1226 & 60 & 25 & Vulnerable \\
\hline Priority 3 & 0.1022 & 59 & 25 & Slightly vulnerable \\
\hline Priority 4 & 0.0000 & 59 & 25 & Secure \\
\hline \multicolumn{2}{|r|}{ Total number } & 237 & 100 & \\
\hline Village priority & $\begin{array}{l}\text { Range of the population to the mini- } \\
\text { mum welfare }\end{array}$ & Number of villages & Percentage $(\%)$ & Vulnerability status \\
\hline Priority 1 & 0.1284 & 59 & 25 & Highly vulnerable \\
\hline Priority 2 & 0.0705 & 59 & 25 & Vulnerable \\
\hline Priority 3 & 0.0327 & 59 & 25 & Slightly vulnerable \\
\hline Priority 4 & 0.0000 & 60 & 25 & Secure \\
\hline \multicolumn{2}{|r|}{ Total number } & 237 & 100 & \\
\hline Village priority & $\begin{array}{l}\text { Range of the number of households } \\
\text { without access to electricity }\end{array}$ & Number of villages & Percentage (\%) & Vulnerability status \\
\hline Priority 1 & 0.0204 & 59 & 25 & Highly vulnerable \\
\hline Priority 2 & 0.0044 & 59 & 25 & Vulnerable \\
\hline Priority 3 & 0.0001 & 59 & 25 & Slightly vulnerable \\
\hline Priority 4 & 0.0000 & 60 & 25 & Secure \\
\hline \multicolumn{2}{|r|}{ Total number } & 237 & 100 & \\
\hline Village priority & $\begin{array}{l}\text { Range of the number of villages with } \\
\text { inadequate transport connection }\end{array}$ & Number of villages & Percentage $(\%)$ & Vulnerability status \\
\hline Priority 1 & 4 & 12 & 15 & Highly vulnerable \\
\hline Priority 2 & 3 & 16 & 7 & Vulnerable \\
\hline Priority 3 & 2 & 25 & 11 & Slightly vulnerable \\
\hline Priority 4 & 1 & 184 & 78 & Secure \\
\hline \multicolumn{2}{|r|}{ Total number } & 237 & 100 & \\
\hline Village priority & $\begin{array}{l}\text { Range of the number of children not } \\
\text { attending school }\end{array}$ & Number of villages & Percentage $(\%)$ & Vulnerability status \\
\hline Priority 1 & 0.0616 & 59 & 25 & Highly vulnerable \\
\hline Priority 2 & 0.0334 & 59 & 25 & Vulnerable \\
\hline Priority 3 & 0.0084 & 60 & 25 & Slightly vulnerable \\
\hline Priority 4 & 0.0000 & 59 & 25 & Secure \\
\hline \multicolumn{2}{|r|}{ Total number } & 237 & 100 & \\
\hline Village priority & $\begin{array}{l}\text { Range of the number of households } \\
\text { without access to clean and safe } \\
\text { drinking water }\end{array}$ & Number of villages & Percentage (\%) & Vulnerability status \\
\hline Priority 1 & 0.1734 & 59 & 25 & Highly vulnerable \\
\hline Priority 2 & 0.0665 & 59 & 25 & Vulnerable \\
\hline Priority 3 & 0.0154 & 59 & 25 & Slightly vulnerable \\
\hline Priority 4 & 0.0000 & 60 & 25 & Secure \\
\hline \multicolumn{2}{|r|}{ Total number } & 237 & 100 & \\
\hline
\end{tabular}




\begin{tabular}{|c|c|c|c|c|}
\hline Village priority & $\begin{array}{l}\text { Range of the number of medical staff } \\
\text { to the population }\end{array}$ & Number of villages & Percentage $(\%)$ & Vulnerability status \\
\hline Priority 1 & 0.0131 & 59 & 25 & Highly vulnerable \\
\hline Priority 2 & 0.0126 & 60 & 25 & Vulnerable \\
\hline Priority 3 & 0.0118 & 59 & 25 & Slightly vulnerable \\
\hline Priority 4 & 0.0000 & 59 & 25 & Secure \\
\hline \multicolumn{2}{|r|}{ Total number } & 237 & 100 & \\
\hline Village priority & $\begin{array}{l}\text { Range of the number of households } \\
\text { without access to a disposal facility }\end{array}$ & Number of villages & Percentage (\%) & Vulnerability status \\
\hline Priority 1 & 0.0294 & 59 & 25 & Highly vulnerable \\
\hline Priority 2 & 0.0080 & 59 & 25 & Vulnerable \\
\hline Priority 3 & 0.0001 & 50 & 21 & Slightly vulnerable \\
\hline Priority 4 & 0.0000 & 69 & 29 & Secure \\
\hline \multicolumn{2}{|r|}{ Total number } & 237 & 100 & \\
\hline
\end{tabular}

(Source: Kutai Kartanegara District Office, 2016).

1, Priority 2, and Priority 3 ranges between $20 \%$ $30 \%$; and (3) low, if the number of villages classified as Priority 1, Priority 2, and Priority 3 is less than $20 \%$. Currently, the level of food insecurity in Kutai Kartanegara is dominated by low food insecurity. The percentage of food secure villages in the district is as high as $82.28 \%$ (195 villages). The sub-districts with a low level of food insecurity status are Samboja, Muara Jawa, Muara Badak, Marang Kayu, Loa Janan, Loa Kulu, Tenggarong, Sebulu, Tenggarong Seberang, Kota Bangun, Kembang Janggut, and Tabang. The sub-districts with a high level of food insecurity status are Anggana, Muara Kaman, Muara Muntai, and Kenohan. The sub-districts with a moderate level of food insecurity are SangaSanga and Muara Wis. The spatial variability of food insecurity, which shows each priority area in the Kutai Kartanegara District, was presented on a map (Fig. 3).

Based on the map shown in Fig. 3, approximately $27.41 \%$ of the sub-districts in Kutai Kartanegara are considered to have a high level of food insecurity, as represented by the red colour. The yellow colour on the map represents $6.14 \%$ of the total area of the district that has a moderate level of food insecurity; the green colour represents $66.45 \%$ of the district that has a low level of food insecurity. Based on this data, two of the vulnerable villages $(2.94 \%)$ are located in the Anggana sub-district. In the sub-districts located in the downstream area, six of the villages $(8.82 \%)$ are slightly vulnerable and 60 villages $(88.24 \%)$ are secure. The midstream area contains four vulnerable villages $(4.49 \%)$, eight slightly vulnerable villages $(8.99 \%)$, and 77 secure villages $(86.52 \%)$. The sub-district in the upstream area has the highest number of villages in the high insecurity food category. All nine $(11.25 \%)$ villages with a highly vulnerable food insecurity status are located in the upstream area. The upstream area has six vulnerable villages $(7.50 \%)$ and seven slightly vulnerable villages $(8.75 \%)$. Typical villages in the upstream area are relatively steep; they lack economic infrastructure and transportation access as well as machinery for agricultural production. Those conditions to some extent have been inhibiting food production, processing and distribution, therefore could cause a low level of food production capacity, underdevelopment of food processing and limited access to food distribution. Although 58 villages $(72.50 \%)$ in the upstream area have a food secure status, yet many of the villages still have a highly vulnerable food insecurity status, the government of the Kutai Kartanegara District should assign an advance priority to the sub-districts located in that area by addressing equitable development both in terms of the physical infrastructure, trade needs, and healthcare because the indicators used to determine food insecurity are correlated to those factors.

\section{Potential of the agricultural sector to cope with the food insecurity issue}

As mentioned above, the agricultural sector plays an important role in national economic development and in the fulfilment of food needs in the Kutai Kartanegara District. The main 


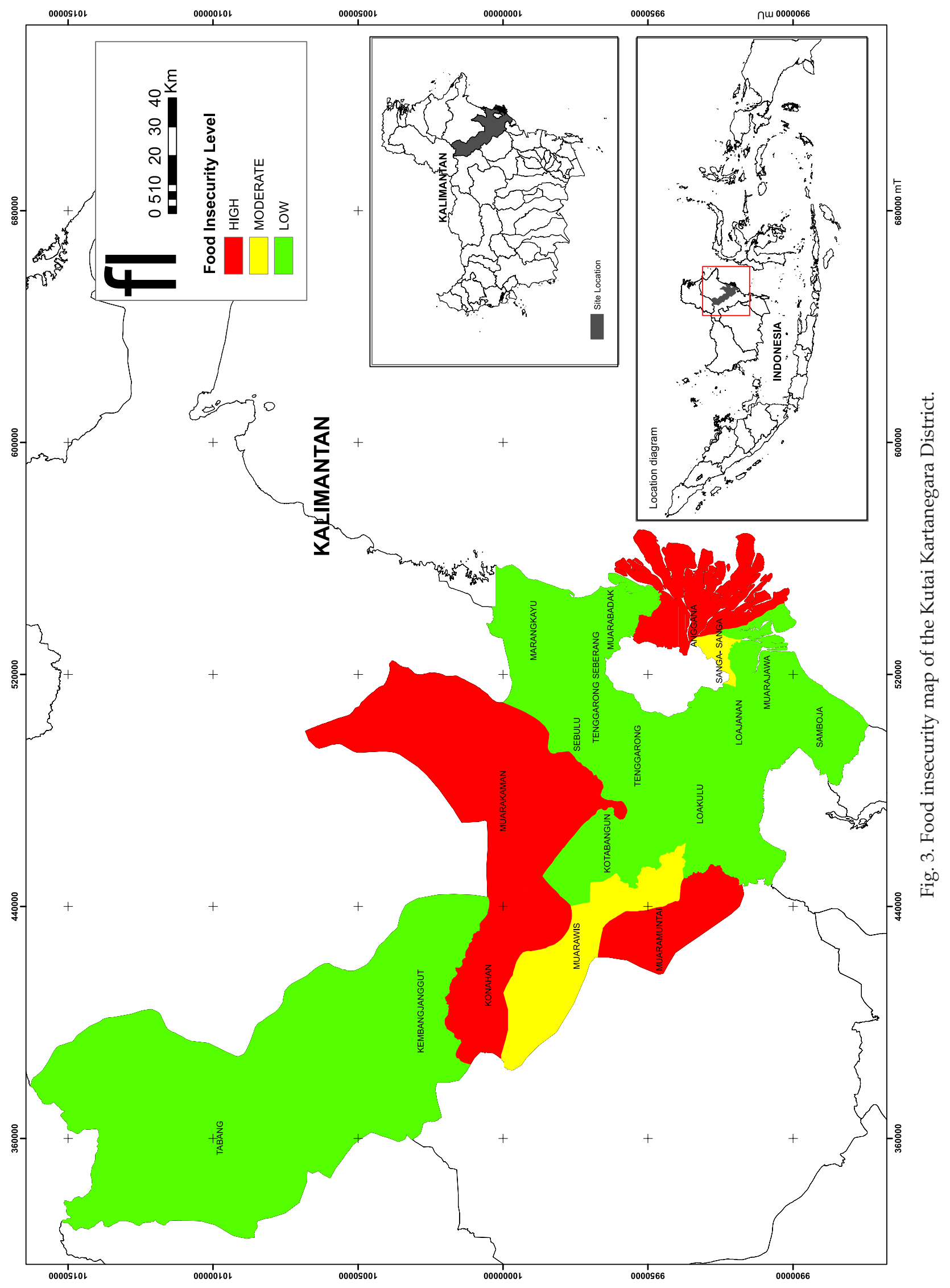


cultivated food crops in that district include rice, maize, cassava, sweet potatoes, peanuts, soybeans, and green beans. However, as the primary food staple in Kutai Kartanegara, the production of rice decreased from 210,230 tons in 2010 to only 186,289 tons in 2015 . This was primarily caused by the decrease in the area of harvested farmland and the stagnant productivity of rice fields. From 2009 to 2015, rice production in the district tended to be stagnant (only 5.10 tons/ha). The areas in Kutai Kartanegara that produce the most rice are the Tenggarong Seberang and Loa Kulu sub-districts, which are located in the midstream area; there, rice production was as high as 128,100 tons $(68.57 \%)$ in 2015. The Marang Kayu and Samboja sub-districts, which are located in the downstream area, yield $18.69 \%$ of the total rice production in Kutai Kartanegara, followed by the Kota Bangun and Tabang sub-districts in the upstream area, which yield $12.75 \%$ of the total rice production.

In addition to rice, cassava and maize are also the major food crops that are staple food in the Kutai Kartanegara District. From 2010 to 2015, maize production also decreased. In 2010, maize production yielded 3,587 tons; by 2015 it had decreased to 1,576 tons. The decrease in the area of farmland is believed to be the main reason for this phenomenon, and this is similar to the reason for the decrease in rice production. However, unlike rice, the production of maize increased to 3.16 tons/ha in 2010 and to 3.75 tons/ ha in 2015. Maize is produced in three sub-districts located in the downstream area. Marang Kayu, Samboja, and Sanga-Sanga produce a total of 1,539 tons $(97.65 \%)$ of maize and the Loa Kulu sub-district produces 37 tons $(2.35 \%)$. Unlike the production pattern for rice and maize, the production of cassava during the same 2010-2015 period increased, despite the decrease in the area of farmland. In 2010, the production of cassava amounted to 20,075 tons, and it increased to 21,700 tons in 2015. Overall, its productivity from 2010 to 2015 also increased from 13.76 tons / ha in 2010 to 22.65 tons/ha in 2015. The Kota Bangun, Tabang, Kembang Janggut, Kenohan, Muara Wis, and Muara Muntai sub-districts produced the majority of cassava, with a yield of up to 9,433 tons $(43.47 \%)$, followed by the Muara Kaman, Tenggarong Seberang, Tenggarong, Sebulu, Loa Kulu, and Loa Janan sub-districts at
7,181 tons (33.09\%) and the Marang Kayu, Muara Badak, Anggana, Sanga-Sanga, Muara Jawa, and Samboja sub-districts at 5,086 tons $(23.44 \%)$.

Judging from the agricultural sector's contribution to employment in 2015, it can be defined as the most strategic sector for employing most of the people in the district. Out of the 275,749 people that comprise the district's working population, the agricultural sector is able to absorb $34.35 \%$ or as many as 94,711 workers. The indicators of the gain of economic development for the agricultural sector can be seen from the rate of farmers exchange value (NTP). In general, the NTP rate in the Kutai Kartanegara District from 2008 to 2015 fluctuated (2007 serves as the base year; the NTP index value for this year is 100), although the NTP rate tends to be increasing. The NTP value in 2008 was 104.13; this decreased to 103.79 in 2009 and increased again in 2010 to 106.73 and to 108.22 in 2011. The NTP value was at its highest level in 2012 when it reached 112.75. However from 2013 to 2015, the NTP value decreased every year until it reached 105.56 in 2015. A macro analysis of the NTP value from 2008 to 2015 shows that it was still above 100 (between 104.13 and 105.56), which means that people who work in the food crop production sector of the agricultural industry can still fulfil their household needs from the workers' salaries and the industry earnings that are obtained in this sector.

\section{Strategic plan to achieve food sovereignty in the Kutai Kartanegara District}

Food insecurity status in the Kutai Kartanegara District has been analysed by considering its level of severity. It is known that the sub-districts located in the upstream area have the highest number of villages in the Priority 1 and Priority 2 categories (15 villages or $18.75 \%$ of the total rural food insecure area), followed by the sub-districts in the midstream area (four villages or $4.49 \%$ of the total rural food insecure area), and the sub-districts located in the downstream area (two villages or $2.94 \%$ of the total rural food insecure area). Strategies to achieve food sovereignty should be developed in the Kutai Kartanegara District, and relevant stakeholders such as Department of Marine Affairs and Fisheries, Department of Agriculture, Animal Husbandry Department, Agency for Regional Development 
Planning, Agricultural Extension Agency, NGOs, as well as local agricultural workers should be invited to participate in developing and supporting those strategies. Each sub-district can optimally develop the potential of local food resources in accordance with the local conditions and the owners of available resources. A complementary relationship between sub-districts can be equitably established in order to achieve a better level of food sovereignty in the future.

Before food sovereignty can be achieved in the Kutai Kartanegara District, some problems related to its potential for land cultivation, human resources, infrastructure development, food production, and food insecurity have to be addressed and solved. The availability of land, food production, access to food and their relationship to the fulfilment of food is still inadequate. From a human resources perspective, the problem is that business is still conducted in the old-fashioned, traditional way, and the quality of education in the district is inadequate. There is also a lack of organisations and institutions where business activities are based on addressing the needs of the community only. There are also constraints on the infrastructure; additional infrastructure is needed that can support farm production and educational and healthcare facilities, and that can ensure the construction of better roads. Lastly, food security is affected by natural disasters and climate change, which remain a major problem in the Kutai Kartanegara District. These factors have to be anticipated in advance; thus, there should be a plan in place to properly mitigate them when they occur.

Officials in the Kutai Kartanegara District are currently facing many real-life problems related to the fulfilment of food, including (1) decreases in the area of farmland and a decrease in soil fertility due to the land being converted into coal mining areas; (2) decreases in food production and food productivity; (3) the limited and uncertain availability of water for food production due to damage to the environment (forests); (4) the lack of irrigation facilities for agricultural production; (5) land damage due to droughts and floods; (6) changes in crop patterns due to climate change; and (7) the high proportion of harvest waste. Based on the FSVA developed by the Food Security Council, Agricultural Extension Services and the World Food Programme (2015), some food insecurity problems are due to a community's limited access to food resources, as represented by the ratio of shops/stalls to the number of households. Other problems are due to limited educational access, which is represented by the ratio of the number of children attending school, or limited access to healthcare facilities, which is represented by the ratio of the number of medical workers to the population. The ratio of the number of households with no access to a disposal facility, the ratio of the number of households without access to clean and safe drinking water, and the lack of general infrastructure, represented by the ratio of households without access to electricity and the ratio of villages with inadequate transport connections, all have an impact on food sovereignty. The critical point in the fulfilment of food needs is actually the condition of social welfare. If members of a community have adequate purchasing power, access to food will be easier; it will also improve the quality of consumed food and build the nutrition-resilience of households' capacity.

Thus, some issues regarding the agricultural sector are of grave concern, including delays during the planting season, because many farming areas have no adequate irrigation network, or the loss of farmland, because it has been converted from the production of agricultural crops to non-agricultural crops (coal mines and oil palm). These issues will be exacerbated by the decrease in the image of agricultural work and agricultural workers, which will result in agricultural labourers needing to become non-agricultural workers. This shift is affected by a variety of factors, including the lack of technology or the lack of an inadequate infrastructure that could support agricultural activities apart from the limited agricultural land that can still be harvested. Moreover, when investors have no guarantee on the availability of farmland for agricultural production, they are less likely to invest in this sector. Furthermore, subsidised fertiliser has not yet been well distributed, and there is no proper place to market the output products so they can be sold and bought effectively. This leads to the low efficiency of agricultural equipment and productivity, as well as underdeveloped agricultural commodities and an underdeveloped post-harvest industry. In addition, the cultural pattern of carbohydrate consumption still highly depends only on rice 
(rice-oriented). Thus, the development of local food resources and foodstuffs based on livestock should also be optimised in the future.

The agricultural development strategy was developed as a response or solution to the various issues officials in the Kutai Kartanegara District face due to global climate change, the reduction of food crop production, the realisation of the competitiveness of the economy amongst citizens based on renewable natural resources, and the need to achieve food security through a diversification program and self-sufficiency. Indeed, global climate change has a negative impact on the existence and sustainability of agricultural production. Shifts in the onset and duration of either the rainy season or the dry season are some indications of the effects of climate change. It impacts the agricultural section by shifting and delaying the planting season, which reduces crop production and industry productivity. Moreover, the irrigation system, which is still inadequate, requires effective and efficient management of water resources. Irrigation systems for farmland should be continuously constructed and maintained. It is also essential to determine the right ratio of land clearing to other land use, for example the ratio of the mining areas and the forested areas in the region should be balanced to maintain the characteristics of East Kalimantan as a wet tropical rain forest area.

The spatial region condition of the Kutai Kartanegara District indicates that it is not yet integrated with the region's development plan. For the record, the detailed regulations and related technical rules about how to convert land from agricultural use to non-agricultural use at the district level is not yet available. As a solution, it is necessary to develop a land status database that can be accessed publicly by relevant agencies and concerned stakeholders such as Department of Marine Affairs and Fisheries, Department of Agriculture, Animal Husbandry Department, Agency for Regional Development Planning, Agricultural Extension Agency, NGOs, Food Security Agency, as well as local agricultural workers. Furthermore, district regulations on the mitigation of land conversion from agricultural productive land to non-agricultural areas need to be developed and implemented. Moreover, former mining areas that are no longer productive should be optimally developed and utilised to grow food crops, as plantations, for animal husbandry, or as fisheries. Toward that end, some possible strategies include: (1) plans for land clearing to create new farmland should be designed to reach 10,000 ha over a period of five years; (2) farming plots should be developed as a model of productive agricultural development; (3) access to financial capital services for agricultural business should be improved; (4) human resources capability should be strengthened and agricultural extension and farming groups should be revitalised; and (5) the management and institutional capacity of the agricultural sector and the institutional capacity of rural economic enterprises and regional economic enterprises should be strengthened to support agricultural business at the regional level.

One important aspect of increasing agricultural production is to preserve productive farmland and ensure the welfare of its workers. If there is nobody to work the land, any attempts to intensify, expand, and diversify the agricultural industry will be meaningless. Nowadays, there is an indication that the agricultural section offers less promising job prospects. Thus, many agricultural production workers, youth in particular, have found jobs in the non-agricultural sector that seem to provide better opportunities. Therefore, in order to manage the sustainability of the agricultural sector, its image needs to be more appealing. Toward that end, many steps should be taken, such as improving and revitalising the agricultural infrastructure (available in every area: upstream, midstream, or downstream), providing necessary agricultural equipment (tractors, threshers, trans-planters, and reapers), building a warehousing, transportation and logistics infrastructure, and creating agribusiness terminals. In fact, in its effort to support agricultural development, the government has already facilitated agribusiness growth by providing direct aid to support the means of production, capital, and business management services for marketing. In addition, the government also provides agricultural extension services to educate and assist farmers. In general, field extension workers are initiators who offer ideas about new innovations that can be applied by farmers or any agricultural workers. The facilitator is expected to provide solutions to the problems faced by farmers to help develop their farming business, motivate 
them, and teach them about the latest agricultural technology, as well as connect them to the relevant stakeholders such as government institution or the private sector that they need.

It is also important to develop a marketing system to enhance production, productivity, and income for agricultural sector workers. Above all, the potential loss of crops due to post-harvest care is still very high in this district; thus, the provision of post-harvest and agricultural processing equipment care is needed, and agricultural workers need to be mentored so they can be sure that their machinery meets equipment standards. Fertiliser distribution is another significant issue. From time to time, fertiliser distribution has been delayed in different areas, which leads to a decrease in agricultural production. To resolve this, people need information about the provision of fertiliser and how to implement it, so that its distribution will be more efficient. Moreover, providing adequate warehousing of the fertiliser and transportation to distribute it, at strategic points adjacent to an agricultural production centre, should be considered.

The weakening of the competitiveness of some superior agriculture products in the Kutai Kartanegara District should also be taken seriously. Revitalising the competitiveness of the products by establishing superior agriculture commodities and convening a task force to oversee the progress are some of the efforts taken to address this issue. Pest and disease prevention and handling should also be integrated quickly by a special task force. The task force is also required to oversee the stability of the agricultural production development as well as the quality of agricultural products, especially for the products that are categorised as superior local commodities. In general, oversight and quality control will ensure that the needs of the minimal processing industry are met. The establishment of superior agricultural commodities can be the basis of a relevant agricultural development policy, which has added value and which is competitive. However, a problem often arises that it can be difficult to identify a superior agricultural product due to poor production stability, an inadequate distribution system, and unidentified market availability. Therefore, it is necessary to develop a pool system of agricultural commodities at the district level so that the amount of raw material is adequate and stable, and sufficiently available. A holistic model of agricultural development that covers all aspects from upstream areas to downstream areas needs to be developed to ensure the availability of raw materials as well as post-harvest handling and processing. The guarantee that both the quality and quality of the raw materials supply will continuously fit the available production capacity over time can also attract investors to this field. This, in turn, will ensure the stability and sustainability of the agricultural sector.

Currently, the high dependency on rice as a staple food remains a common issue. Overcoming the burden of the increasing demands for continuous rice production requires strategic planning. High dependency on rice as a staple food is mostly caused by the cultural consumption of that grain; currently, there is no alternative prospective competitive food that could serve as a replacement. Therefore, the post-harvest industry development of non-rice food products, which are as durable as rice, is needed. A policy to optimise marginal lands for the production of other local food, such as sago, cassava, or sorghum, has not yet been developed. Changes in public perceptions about rice as the only staple food are needed. A suitable non-rice food production program should be developed to anticipate the future threat of rice scarcity, and also to fulfil people's needs. Currently, the food production priority is still oriented to the fulfilment of food for local needs only, not to exports. With the support of various related programs, the production of non-rice food can also be improved. Thus, in addition to meeting the needs of local markets, non-rice food can be developed as an export-oriented product that can also enhance local welfare by diversifying and expanding the market for locally grown and produced food.

\section{Conclusion}

The analysis and discussion of the results showed that, of the 237 villages located in the Kutai Kartanegara District, nine $(3.80 \%)$ are in the Priority 1 category due to their highly vulnerable food insecurity status; 12 (5.06\%) are in the Priority 2 category due to their vulnerable food insecurity status, and 21 (8.86\%) are in the Priority 
3 category, due to their slightly vulnerable food insecurity status. Lastly, 195 villages (82.28\%) are in the Priority 4 category due to their food secure status. From the research results it can be concluded that, in general, the food insecurity status in the Kutai Kartanegara District is low. Thus, at the village level, the area's food status is secure. However, some areas still suffer from high vulnerability to food insecurity, especially villages in the upstream area. High food insecurity in the upstream area occurred in 15 villages in the Muara Muntai and Kenohan sub-districts. High food insecurity also affected four villages in the midstream area in the Muara Kaman sub-district and two villages in the downstream area in the Anggana sub-district.

Based on the description and discussion presented in the previous section, in order to achieve food sovereignty in the Kutai Kartanegara District several factors should be considered: (1) the provision of food (land, production, its availability and its access); (2) human resources (old-fashioned business activity and its institutional, inadequate quality of education); (3) infrastructure (agricultural production facilities, road, education, healthcare); (4) natural disasters and climate change; and (5) diversity of food consumption patterns and culture. Adequate policy regulations, a sufficient food supply, and increased food production are crucial components of achieving food sovereignty. Strategies can be developed to achieve food sovereignty based on the results of both the data analysis and the field observations. Some strategies can be implemented to strengthen regulations, such as shifting land use in the region so former mine areas can be used for related agricultural activities in order to overcome the limited area of farmland. This implementation should also be followed by improvements in the quality and quantity of agriculture commodity production. The community's welfare should also be improved by a food diversification program that upgrades superior food products and by programmes that invest in agricultural sector development. Furthermore, the synergistic coordination among relevant agencies and stakeholders should also be improved to ensure that everything is on the right track.

To strengthen the region's human resources capacity, strategies could be implemented to improve the capability and productivity of businesses, including the ability to add value to products as well as enhance and increase the economy of scale. It is also important to strengthen farming-related institutions, such as farmer groups or associations. The adaptation and mitigation of negative impacts due to climate change and natural disasters should be done by sustainably optimising the utilisation of agricultural resources as well as promoting the use of adaptive technology. Most importantly, it is necessary to build community awareness about natural disasters in order to create an environment in which people can be responsive and know exactly how to cope with the aftermath, especially when floods and landslides occur, so the losses can be minimised.

Another infrastructure development strategy for the agriculture sector is to increase the accessibility to central areas of agricultural production. This can be done by developing an infrastructure that can support integrated agricultural activities. Providing electricity and creating a drinking-water supply infrastructure for agricultural and rural areas are equally important, as is securing water resources to irrigate agricultural land. Moreover, a good drainage infrastructure with a centralised and decentralised system should be developed and implemented based on the potential needs of an area; a waste disposal system and infrastructure for both household waste and agricultural waste is also essential. Rural areas should be fully equipped with healthcare and educational facilities. Lastly, the development of an agricultural information system and agricultural markets is expected to boost the economic health of the area, and of adjacent areas. The diversification of food development based on local resources as well as a campaign to promote the effectiveness of diverse food consumption patterns should be conducted to address the cultural changes and food consumption patterns of people in the Kutai Kartanegara District.

Those strategies were developed to solve the food insecurity issue from the perspective of the agricultural food crop sector. Nevertheless, food security is a multi-sector problem that also includes social, economic, and physical factors. Therefore, the local government of the Kutai Kartanegara District should develop a district master plan as a strategic road map to ensure thoroughly food sovereignty in the region. Such 
a plan should address not only the agricultural sector but also all related sectors and factors, since the food security issue needs an effective, integrated strategy with a multi-sector scope. Focus group discussions (FGDs) on the issue and food security status in surveyed area were very important since the process was also the mechanism to improve data validity and reliability. Through FGDs, related data gathered through primary data collection and secondary data from related agencies could be confirmed and crosschecked with key informants who have enough knowledge and understanding on food security status in the area, therefore the method also played an important role for improving the quality of related data and information.

\section{Acknowledgement}

Part of this paper was developed based on information contained in the report written for the project, Masterplan Kedaulatan Pangan Kabupaten Kutai Kartanegara 2016, which was collaborative effort between the Centre for Economic and Public Policy Studies (PSEKP) UGM and the Agency for Regional Development Planning (BAPPEDA) of the Kutai Kartanegara District. The project was funded by the Kutai Kartanegara District Office (No: 783.2/PSEKPUGM/Pnl/V/2016). The authors wish to thank two anonymous reviewers for their valuable suggestions and corrections.

\section{References}

Agus C., Karyanto O., Kita S., Haibara K., Toda H., Hardiwinoto S., Supriyo H., Na'iem M., Wardana W., Sipayung M.S., Khomsatun, Wijoyo S., 2004. Sustainable site productivity and nutrient management in a short rotation plantation of Gmelina arborea in East Kalimantan, Indonesia. New Forest 28: 277-285.

Anderson M.D., 2013. Beyond food security to realizing food rights in the US. Journal of Rural Studies 29: 113-122.

Azeem M.M., Mugera A.W., Schilizzi, 2016. Living on the edge: Household vulnerability to food-insecurity in the Punjab, Pakistan. Food Policy 64: 1-13.

Barnidge E., LaBarge G., Krupsky K., Arthur J., 2017. Screening for food insecurity in pediatric clinical setting: Opportunities and barriers. J Community Health 42: 51-57.

Bommarco R., Kleijn D., Potts S.G., 2013. Ecological intensification: Harnessing ecosystem services for food security. Trends in Ecology and Evolution 28:

Bosma R., Sidik A.S., Zwieten P., Aditya A., Visser L., 2012. Challenges of a transition to a sustainably managed shrimp culture agro-ecosystem in the Mahakam delta, East Kalimantan, Indonesia. Wetland Ecol Manage 20: 89-99.

BPS, 2013. Agricultural Census 2013. Central Bureau of Statistics, Jakarta.

BPS, 2015. Kutai Kartanegara District in Figures 2015. Central Bureau of Statistics, Kutai Kartanegara.

BPS, 2016. Kutai Kartanegara District in Figures 2016. Central Bureau of Statistics, Kutai Kartanegara.

Chaifetz A., Jagger P., 2014. 40 years of dialogue on food sovereignty: A review and a look ahead. Global Food Security 3: 85-91.

Crush J., Caesar M., 2014. City without choice: Urban food insecurity in Msunduzi, South Africa. Urban Forum 25: 165-175.

De Miguel F.J., Llop M., Manresa A., 2014. Sectoral productivity gains in two regional economies: Key sectors from a supply-side. Ann Reg Sci 53: 731-744.

Denney J.T., Kimbro R.T., Heck K., Cubbin C., 2017. Social cohesion and food insecurity: Insights from the Geographic Research on Wellbeing (GROW) study. Matern Child Health J 21: 343-350.

Dinc M., Haynes K.E., Tarimcilar M., 2003. Integrating models for regional development decisions: A policy perspective. Ann Reg Sci 37: 31-53.

Kutai Kartanegara District Office, 2016. Masterplan Kedaulatan Pangan Kabupaten Kutai Kartanegara 2016. (Masterplan of food sovereignty in the Kutai Kartanegara District 2016). Kutai Kartanegara District Office, Kutai Kartanegara. (Unpublished report) [in Bahasa Indonesia].

Food Security Council, Agricultural Extension Services, and World Food Programme, 2015. Food security and vulnerability atlas of Indonesia 2015. Dewan Ketahanan Pangan, Kementerian Pertanian and World Food Programme (WFP), Jakarta.

Funakawa S., Makhrawie M., Pulunggono H.B., 2009. Soil fertility status under shifting cultivation in East Kalimantan with special reference to mineralization patterns of labile organic matter. Plant Soil 319: 57-66.

Hanjra M.A., Qureshi M.E., 2010. Global water crisis and future food security in an era of climate change. Food Policy 35: 365-377.

Hassen K., Zinab B., Belachew T., 2016. Gender and education as predictors of food insecurity among coffee farming of the Jimma zone, Southwest of Ethiopia. BMC Nutrition 2:75.

Jablonski B.B.R., McFadden D.T., Colpaart A., 2016. Analyzing the role of community and individual factors in food insecurity, identifying diverse barriers across clusters community members. J Community Health 41: 910-923.

Jamhari, 2011. Analisis Ketahanan Pangan Rumah Tangga, Seminar Nasional Hasil Penelitian Sosial Ekonomi Pertanian. Faculty of Agriculture UGM, Yogyakarta.

Kneafsey M., Dowler E., Lambie-Mumford H., Inman A., Collier R., 2013. Consumers and food security: Uncertain or empowered? Journal of Rural Studies 29: 101-112.

Kollannoor-Samuel G., Wagner J., Damio G., Segura-Perez S., Chhabra J., Vega-Lopez S., Perez-Escamilla R., 2011. Social support modifies the association between household food insecurity and depression among Latinos with uncontrolled type 2 diabetes. J Immigrant Minority Health 13: 982-989.

Koren O., Bagozzi B.E., 2016. From global to local, food insecurity is associated with contemporary armed conflicts. Food Sec 8: 999-1010. 
Larochez-Dupraz C., Huchet-Bourdon M., 2016. Agricultural support and vulnerability of food security in developing countries. Food Sec 8: 1191-1206.

Li H., Zhang X., 2017. A spatial explicit assessment of food security in Africa based on simulated crop production and distribution. Journal of Cleaner Production 147: 628-636.

Mammen S., Bauer J.W., Richards L., 2009. Understanding persistent food insecurity: A paradox of place and circumstance. Soc Indic Res 92: 151-168.

Mosher A.T., 1966. Getting agriculture moving: Essentials for development and modernization. Praeger, Madison.

Markwick A., Ansari Z., Sullivan M., McNeil J., 2014. Social determinants and lifestyle risk factors only partially explain the higher prevalence of food insecurity among $\mathrm{Ab}$ original and Torres Strait Islanders. BMC Publich Health 14: 598.

Musemwa L., Muchenje V., Mushunje A., Aghdasi F., Zhou L., 2015. Household food insecurity in the poorest province of South Africa: Level, causes, and coping strategies. Food Sec 7: 647-655.

Nalty C.C., Sharkey J.R., Wesley R.D., 2013. Children's reporting of food insecurity in predominately food insecure households in Texas border colonias. Nutrition Journal 12: 15.

Paloviita A., Kortetmaki T., Puupponen A., Silvasti T., 2016. Vulnerability matrix of the food system: Operationalizing vulnerability and addressing food security. Journal of Cleaner Production 135:

Pinstrup-Andersen P., 2009. Food security: Definition and measurement. Food Sec 1: 5-7.

Potochnick S., Chen J., Perreira K., 2016. Local-level imigration enforcement and food insecurity risk among His- panic immigrant families with children, national-level evidence. J Immigrant Minority Health. doi: 10.1007/ s10903-016-0464-5.

Rattan L., 2013. Food security in a changing climate. Ecohydrology \& Hydrobiology 13: 8-21.

Retnowati A., Anantasari E., Marfai M.A., Dittmann A., 2014. Environmental ethics in local knowledge responding to climate change: An understanding of seasonal traditional calendar pranotomongso and its phenology in Karst Area of Gunungkidul, Yogyakarta, Indonesia. Procedia Environmental Sciences 20: 785-794.

Shone M., Demissie T., Yohannes B., Yohannis M., 2017. Household food insecurity and associated factors in West Abaya district, Southern Ethiopia, 2015. Agric \& Food Secur 6: 2-10.

Steckley M., 2016. Why 'race' matters in struggle for food sovereignty: Experiences from Haiti. Geoforum 72: 26-29.

Stephens E.C., Jones A.D., Parsons D., 2017. Agricultural systems research and global food security in the 21st century: An overview and roadmap for future opportunities. Agricultural Systems.

Subejo, 2011. Bunga Rampai Pembangunan Pertanian dan Pedesaan. Universitas Indonesia Press, Jakarta.

Subejo, Arifa N., Mustofa M., 2015. Lima Pilar Kedaulatan Pangan Nusantara, 2nd edition. UGM Press, Yogyakarta.

Suhardjo, 1994. Trend of food consumption versus desirable dietary pattern. Indonesian Food Journal 9: 55-65.

Tawodzera G., 2011. Vulnerability in crisis: Urban household food insecurity in Epworth, Harare, Zimbabwe. Food Sec 3: 503-520.

WFP, 2010. Comprehensive food security and vulnerability analysis guidelines. First edition. WFP, Rome. 